\title{
High Five Strategy to Improve Students' Reading Comprehension
}

Susi Purnama Sari ${ }^{1}$, Hermawati Syarif ${ }^{2}$, Jufrizal ${ }^{3}$

1,2,3. Universitas Negeri Padang, Indonesia

Corresponding Author: Susi Purnama Sari, E-mail: strangers13@yahoo.com

\begin{tabular}{cl} 
& \multicolumn{1}{c}{ ABSTRACT } \\
\cline { 2 - 3 } & $\begin{array}{c}\text { This article aimed to know the improvement of students' reading } \\
\text { comprehension of narrative text after using High Five strategies and } \\
\text { common factors influenced the changes of students' reading }\end{array}$ \\
comprehension of narrative text by using High Five strategies at XI \\
ARTICLE INFO & IPA 2 of Senior High School 1 Merangin Jambi. The result showed that \\
Article history: & in two cycles to answer these research questions: first, the students' \\
Received & mean score improved 22,44 point or 26\%; second, these improvements \\
15 November 2018 & were influenced by students' reading interest and motivation, \\
Revised & materials selection, and reading strategies. In conclusion, this research \\
30 April 2019 & showed that the use of High Five Strategy could improve students' \\
Accepted & reading comprehension of narrative text at XI IPA 2 of Senior High \\
2 June 2019 & School 1 Merangin Jambi.
\end{tabular}

Keywords: High Five Strategy, Reading Comprehension, Factors in Students' Reading Comprehension

DOI $\quad:$ https://doi.org/10.25217/ji.v4i1.349

Journal Homepage $\quad:$ http://journal.iaimnumetrolampung.ac.id/index.php/ji/

This is an open access article under the CC BY SA license

: https://creativecommons.org/licenses/by-sa/4.0/

\section{INTRODUCTION}

Teaching reading comprehension focusing on text genres should be carefully prepared and considered since students' mostly asked to answer the questions related to the text in their reading activity. The previous research wrote by Smith \& Goodman (1991) entitled On the Psycholinguistic Method of Teaching Reading stated that Students will be able to read and comprehend the reading text fluently if they are able to predict what they are going to read. There also Alyousef (2006) entitled Teaching Reading Comprehension to ESL/EFL Learners, stated on his article that reading can be seen as an inteactive process between a reader and a text which leads automatically. The differences between this study with the previous one is that, Both of those researches told us how to comprehend reading fluently but doesn't define the best strategy to achieve it. Therefor this reseach is quitely important to discuss because it define the strategies how to comprehend rading fluently. High Five Strategies consists of five reading strategies namely; first, activating backgound knowledge; second, 
questioning; third, analyzing text structure; fourth, creating mental images; and the fifth, summarizing. These five strategies are believed having the best impact to teach reading comprehension.

The questions are generally about main idea, topic sentence, implied details, rare vocabularies, text pattern, the generic structure, and so on. From all of these questions, actually there is a part of the text which is believed as the key to comprehend the text, that is the text pattern. Granger (2004) stated that recognizing the pattern of organization is important in reading for comprehension. They assume that the authors present their ideas in certain patterns to make sense. From this opinion, teaching text structure or pattern of organization is urgently needed. Heckelman (1969) stated on his article that the general public has shown great concern about he state of reading in the school. Understanding the pattern will enable the students to find the location of the topic sentence, main idea, supporting details, sentence connectors, and concluding sentence. Thus, the text can be fully understood and the questions related to the content of the text can be easily answered. As the implication, reading comprehension strategies which focus on text pattern and structure is needed.

In this research, since text genre was the focus of English teaching in senior high school, the researcher tried to implement the strategy which was emphasized on reading texts. The strategy is called High Five. High Five as quoted from Dymock \& Nicholson (2010) consists of five reading strategies namely; first, activating backgound knowledge, in which the teacher stimulates the students by inviting them to recall their knowledge about the text before they are going to read, the stimulates need to provide into reading process and the process of learning to read; second, questioning, the teacher gives students some questions related to the text to encourage the students' curiosity and willingness to start their reading; third, analyzing text structure, the teacher explains the structure of the text to help the students following the author thoughts, finding main idea, topic sentence, and details; fourth, creating mental images, this strategy stimulates the students to visualize what happen in the text; and the fifth, summarizing,this strategy enables the students to restate the main points and delete irrelevant details which show the full understanding of the whole text. These five strategies are believed having the best impact to teach reading comprehension. Its inline to what Pratiwi (2017) stated on her article that the teacher should use the proper methode and approach in the righ time to get the maximum result of learning. And also what Abu-Rabia \& Siegel (2002) stated that there was significant relationshipbetween the acquisition of word and pseudo-word reading working memory. In the application of these 
strategies, they are not taught one by one in a separated way. These strategies are applied in integrated steps of teaching. In pre-activity of the learning, teacher can start by activating the students' background knowledge. In the main activity, students are asked many questions related to the text, or they may do questioning by themselves. After that, the text's structure is analyzed. This analysis is hoped that the students are able to find how the text is organized that thus they may find the author's thoughts. Students then visualize what the text is about. They create a mental image of the text being read. In the last activity, to close the lesson, students should be able to summarize the text by restating main idea, and delete unnecessary details.

Students in SMAN 1 Merangin especially at class XI IPA 2 were unenthusiastic to follow the lesson, reading material in particular. Some students stopped their reading when they were confronting with unfamiliar words in text. Students translated each word they read by using bilingual dictionaries. When they were asked about the content of the text, most of the students were silent and had nothing to answer. From the reading test, it is found that the students had low ability in reading. Only some students got high score, while most students failed. There were 24 students failed, or about $80 \%$ from all; while only 6 students or $20 \%$ completed the standard of KKM which was set at average score 75 , with the classical completeness was $85 \%$. Therefore, it needed an urgent solution. This research was limited on the use of High Five reading strategy to improve the students' reading comprehension of narrative text. Besides, this research also focused at describing common factors that influenced the changes of the students' reading comprehension of narrative text at XI IPA 2 of SMAN 1 Merangin Jambi in the academic year of 2014/2015.

\section{RESEARCH METHOD}

This research was designed in the form of classroom action research. Mertler (2006) write that, "action research is a type of practitioner research that is used to improve the practitioner's practice; action implies doing or changing something." Classroom action research is done by the school's practitioners in order to change or something that has positive impacts to the teaching learning activities.

There were two cycles in this research. Each of the cycle had several phases, they were planning, acting, observing and evaluating, and reflecting. One cycle in this research consisted of four meetings, while for each meeting equals with $2 \times 45$ minutes. 
SMAN 1 Merangin is located at Jalan Gunung Masurai, Pasar Atas Bangko, Merangin Regency, Jambi Province. There were nine classes at second grade in this school divided into two majors: science and social class. There were five classes of science and four classes in social major. The research was conducted in science class XI IPA 2, since the researcher taught and found reading comprehension problems in this class. The object in this research was the English learning process focusing on reading comprehension activity.

The sample was taken from the second grade students of SMAN 1 Merangin that was class XI IPA 2. The total number of the students were 30 students, consisted of 20 females and 10 males. To help the researcher indoing this research, a collaborator was taken from another English teacher, she was Lestari, S.S. The collaborator was needed to help the researcher to plan the classroom activities, observe while the activities were taking place, help in analyzing the data and draw the conclusion of the development and improvement in each cycle.

In evaluating the teaching and learning process in cycle I and II, data from the observation sheets, and interview transcript, were analyzed and scored. Each of the indicator of observation sheets was calculated and compared to find its mean/average from meeting to meeting to see the improvements of the teaching and learning process. To find the score for each of the sheets, the following formula was used:

$$
\begin{aligned}
& \bar{X}=\frac{\sum X \times 2}{N} \\
& \text { in which } X=\text { average score } \\
& \sum X=\text { total score } \\
& N=\text { total number of items }
\end{aligned}
$$

On the other hand, to know the students' result in reading comprehension teaching and learning process, the data got from the reading tests were calculated and scored. Tests were given in the fourth meeting at the end cycle I and cycle II. There were 15 items of the tests, consisted of 10 items for multiple choice questions, and 5 items for True-False questions. To get the score, the following formula was used:

Students' Score: Total of correct answer X 100

Number of items 
The scores from the tests then were compared from cycle to cycle to see the increasing mean of score among the cycles, that determined the improvement of the learning results in this research. Data of the tests were got from precycle test, cycle one and cycle two test. The researcher then collected and classified data got from observation sheets, and tests. To support and complete them, teacher conducted interview with the students to find the factors influenced teaching and learning on reading comprehension activity. Teacher interviewed the most representative students at the end of the cycle based on their achievement during the tests.

The data that were in the form of scores or numbers were got from doing statistical data analysis. The data from the students' reading comprehension from cycle to cycle test were analyzed quantitatively to find mean or average score and the percentage to see the lesson completeness. Teacher used the following formula as suggested by Gay \& Diehl (1992) to find mean score of reading comprehension test:

$$
\bar{X}=\frac{2 X}{\mathrm{~N}}
$$

Where: $X=$ Mean

$\sum X=$ The sum of all the scores

$\mathrm{N}=$ The total number of the students

In both cycle I and cycle II tests, the teacher scored the students' sheets and wrote the scores into tables. The whole scores were then calculated to find the percentage of classical classroom completeness. To do this, Sudijono (1998) suggests the following formula.

$$
P=\frac{F}{N} \times 100 \%
$$

Where:

$\mathrm{F}=$ frequency

$\mathrm{P}=$ Percentage

$\mathrm{N} \quad=$ Number of students

Students completed the KKM score when they achieved standard score 75, and classroom completeness got $85 \%$. Teacher counted and calculated the total of students who fail and complete the KKM in each of the cycle.

\section{FINDINGS AND DISCUSSION}

In Precycle test the mean score from the total numbers of students was 64,22 point. From the result of this test, it was found that translating several vocabularies in context got the highest scores. While in the other hand, 
analyzing the paragraph pattern was at the lowest score. No students seemed understood the pattern of the paragraph. In addition, they were also still struggling in finding main idea, making inference, guessing details, identifying the generic structure, and making summary. Comparing with the KKM score which was set at 75, in this precycle test the students' result of reading comprehension tests was not complete yet. From the total numbers of students that was 30 students, there were only 6 students passed the KKM score or about $20 \%$ of the whole. While the students who failed in achieving KKM were 24 students or about $80 \%$. In the other hand, the ideal KKM achievement should be $85 \%$. From this result, CAR was seen very urgent to conduct.

Gambar (Figure) 1.

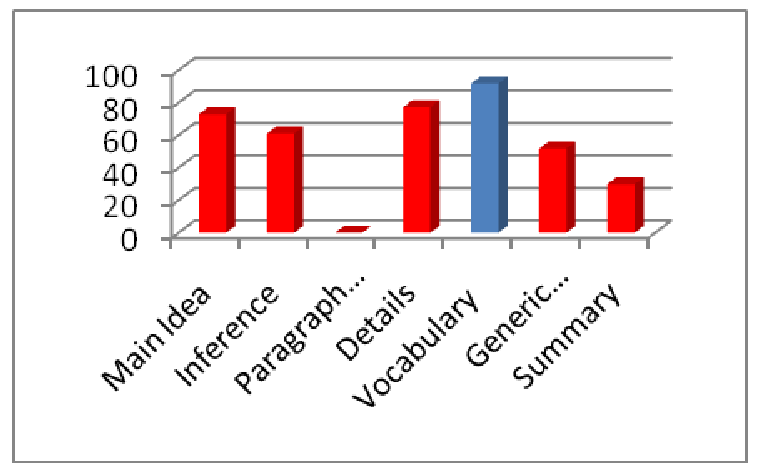

From the result of cycle I test, there was an improvement on the average or mean score of the total numbers of students. The mean score in this cycle I was at 70,22 point. The highest score was translating vocabulary with 98,57 point while the lowest one was still paragraph pattern with 0 point. These results can be also clearly seen in the following graph:

\section{Gambar (Figure) 2.}

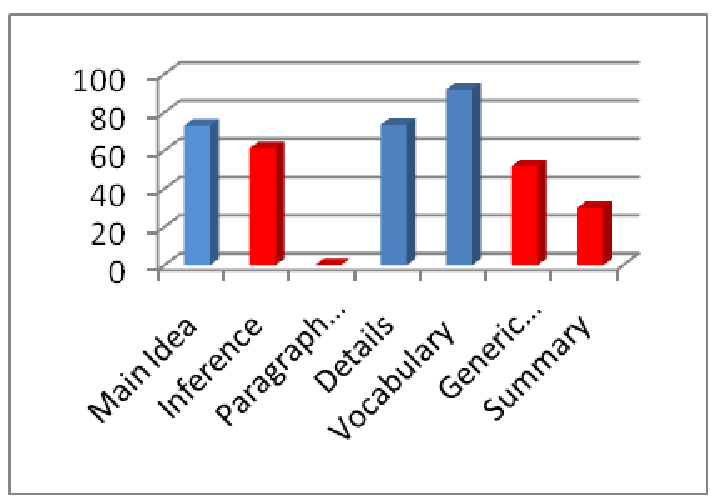


In this cycle, the $K K M$ set was 75 , so the learning was still unsatisfactory yet to complete the KKM. In the other hand, from 30 students in this cycle I, there were 8 students or around 26,7\% who completed the KKM score. While 22 students or about $73,3 \%$ still failed.

In cycle II, the average score of the students' result in this cycle II achieved 86,67 with complete criteria. The highest score was translating vocabulary in context with 93,53 point while the lowest one was identifying main idea with 46,42 point. The following graph is provided to see the result:

Gambar (Figure) 3.

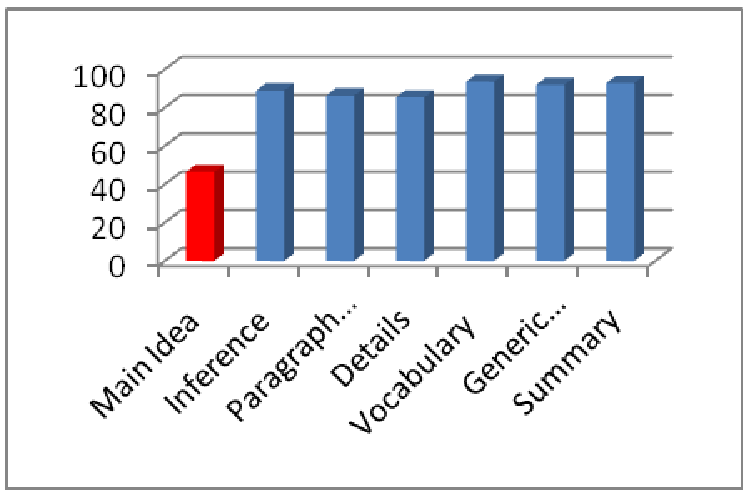

From the result of the research, the researcher found many changes occured in the teaching and learning activities which might influence this result. When the researcher decided that the research had been stopped at the end of the second cycle, an interview was conducted to the students to dig deeper the application of High Five strategies as well as the students feelings, thoughts, and or comments toward the research. There were 22 students chosen randomly from 30 students. The first factor arisen as the first question was about the students' reading interest and motivation. As stated by Rusman (2017) that motivation factor is much influential in the students' learning. From the interview data, the researcher found most of the students were motivated to read. It can be proven that when almost all of them answered their likeliness in reading. Students mostly like reading for various reasons, such getting new information and knowledge from reading, it's interesting, adding insights and knowing new things and for pleasure only. Verily, few answers shown that few of them dislike reading, such as S10, "Don't really like Miss.Yeah, sometimes it's bored" and S 21, "I don't like much Miss, I don't like reading lessons." Meanwhile some other answers S 4, 19, 20: "It depends on the story." The researcher concluded that from the students' answers, basically most of them 
like reading. However, they had different choices and preferences of reading materials.

Second factor was materials selection. It consists of students' preferences books to read and text types. Most of the students are reading for pleasure, few of them are reading for academic reason. When they are asked the materials they are more triggered to read, their answers can be like novels, legends, fairy tales, or urban legends. Students' code 1, 2, 3, 4, 6, 9, 10, 12, 14, 16, 19, 20, 21, 22 answered that "novel" is their favorite reading materials. When the students were asked about their opinion related to the easiest and the most difficult text types, students' code 2, 6, 7, 8, 9, 12, 13, 14, and 20 thought that narrative was the easiest. While students' code $4,5,15,16,17$, and 22 considered that narrative was the most difficult. Considering the students mostly like novel as their favorite reading materials, it can be assumed that this is the reason why they enjoy narrative. Novel as literary genre is mostly written in narrative, using chronological order. Both novel and narrative text have potential to create the students' imagination. As Faridi \& Bahri (2016) define on his article that state that those literary genre may improve community participation by enggaging in literacy activities which led to a lifetime habit of reading.

Next factor was reading strategies, either used by the teacher and students, and their attitude in reading. Teacher asked five questions related to these factors. Students' answers related to reading strategies showed their opinion about High Five strategies. Students tended to use no strategy before. Most of them felt helpful by the application of High Five strategies to help them read. Its also has same definition to what Hatam, Sudibyo, \& Wibowo (2018) said that the teacher are going to make the student enjoy in teaching learning process.

Research showed that students' reading comprehension of narrative text at XI IPA 2 of SMAN 1 Merangin Jambi had been improved significantly. Based on the data analysis, it was found that identifying main idea was the lowest indicator achieved by the students since at the end of the second cycle of this research it was still incomplete. It can be assumed that students need to practice analyzing text structure strategy in High Five intensively. In the other hand, translating vocabulary in context was the highest indicator completed by them. It is believed that materials selection such as choosing appropriate narative text selection which suited with the students' background knowledge that was science influenced and helped the students to translate the contextual vocabularies. Most of the titles were about the story of the animals which added their English vocabulary especially the name and characteristics of animals. 
Besides, in selecting materials the teacher also used chart, powerpoint slides, videos, and flashcards where necessary.

The first indicator was identifying main idea. It was complete in the first cycle, but then decreased or was incomplete in the second cycle. This result could be caused by the lack practicing of summarizing strategy since this strategy as commented by Guthrie, Wigfield, \& Perencevich (2004) refers to forming an accurate, abstract representation of text after reading all or a substantial portion of material. Students also need to practice analyzing text structure strategy more often in other reading experience with various text types since at the end of the second cycle it remained incomplete. In precycle test, the average score for this indicator was 4,89, it improved to 6 in cycle I test, but decreased at the end of the second cycle to 3,11. Other assumption that caused this is students might be difficult in choosing similar answers. Question could be too difficult for them.

The second indicator was making inference. Total improvement was 5,56 point or $27,8 \%$. This improvement could be assumed by the effective use of creating mental images strategy in which the students constructed their imagination and then they were able to know what's implied in the story. In addition, questioning strategy had created students' critical thinking to guess the hidden facts from details. As stated by Nelson \& Writing (1989) that students can ask a right there question such as "what are the facts here?" that helped them to dig the story deeper and what's beyond that.

The third indicator was the most difficult one for the students in the early cycles. It was identifying text pattern. Students firstly did not understand that knowing text pattern is very essential to follow the author thoughts. Nobody could answer its question in pre-cycle and cycle I test. It then surprisingly improved at second cycle to 5,78 point or about $86,3 \%$ improvement. Since the text type in this research was focused on narrative, in which its text pattern is chronological order, then the teacher taught the students about this pattern. When they understood the pattern by using analyzing text structure and summarizing strategies, the score then improved significantly from zero to complete.

The fourth indicator was guessing details. In this indicator, students guess what is stated and unstated that can be drawn from supporting details. It improved slightly until the end of the cycle. Activating background knowledge was really helpful in enhancing students' comprehension from their beginning reading activity which enabled them to understand narrative. Additionally, analyzing text structure strategy had led the students to connect the details. The use of integrated strategy like activating background knowledge, 
questioning, and creating mental images strategy were contributive to infer what is not stated in details. As summarized from Dymock \& Nicholson (2010) that activating schemata enables the students to infer context that is not explicit, while questioning can explore what is beyond the text, and visualizing helps to establish imagination of what might be unseen in the text.

The fifth indicator was translating vocabulary in context which had surprising result since in the early investigation it was assumed that the students had limited contextual vocabularies. Selective decision in choosing relevant narrative texts' titles to the students was believed as the main reason. Furthermore, a good starter by activating schemata in the beginning which then helped by other media like flashcards, and videos had helped the students translated the certain words in texts correctly. However, few of them still looked up their dictionaries to tackle the unfamiliar words found.

Analyzing generic structure was the sixth reading comprehension indicator which really suit with the analyzing text structure strategy. However, in analyzing text structure, the concern was not only about text's generic structure, it also included text's pattern, discourse markers, topic sentence, and details. In the other hand, analyzing generic structure especially for narratives was seen from its orientation, complication, resolution and/ or coda. So, the teacher focused analyze the text based on what was needed by the students. analyzing generic structure improved and complete. This result supports opinion from Wassman \& Rinsky (1999) that it makes the readers easier to understand the core messages conveyed.

The last indicator was writing summary which according to Parks (2014) is the ability to delete irrelevant details, combine similar ideas, condense main ideas, and connect major themes into concise statements that capture the purpose of a reading for a reader. This indicator improved consistently and complete at the end of the cycle. It also really suited with summarizing strategy. In teaching this strategy, teacher also employed other media like provided charts to help the students only put the important points they found in the text.

The changes of significant improvements of the students' reading comprehension of narrative text were caused by several influential factors. From the data transcription got by doing interview to the students, there were three main influential factors, they are students' reading interest and motivation, materials selection, and students' reading strategies.

The first factor was students' reading interest and motivation. Atwell (2007) argues that motivation is one of influential factor coming from the students. Besides, other factors like students' inequalities, style, learning preferences, talents, and aptitude were also influential. In this research, the 
students' motivation was specified and seen from learning reading comprehension aspect. Based on the findings during this research, the students previously were unenthusiastic to follow reading lesson that they then had lack of motivation to do so. In interview, the researcher asked their motivation and whether they are interested to read. Almost all of them admitted they liked reading. Few of them disliked it. Those who disliked it commented that, “...sometimes it's boring" or "I don't like reading lessons." While those who were motivated to read, did it by many reasons such as adding knowledge, knowing new thing, getting pleasure, and so on.

The second factor was materials selection. Materials given should be based on the students' interest and background knowledge. It included text types, media, and sources in learning. This factor was from the teacher's side. It suits with the opinion from McKernan (1996) that from the teacher, the factors are about classroom management, teacher's instructional strategy and design, learning media and sources, materials, and curriculum implementation. The teacher chose very selective narrative text's titles which appropriate with the background of the students' major, Biology. Texts' titles were chosen about the story of animals. In addition, other media such as infocus with powerpoint presentaition containing learning pictures or videos, flashcards, and charts, were employed effectively to set an interesting reading experience for the students.

The third factor was reading strategies. As defined by Mc Namara (2007) as a systematic sequence of steps for understanding a text, it was then proved that reading comprehension strategy was really influential in the reading teaching and learning process. The strategy used by both teacher and students was High Five strategies namely activating background knowledge, questioning, analyzing text structure, creating mental images, and summarizing. Six meetings in two cycles of the research had practiced the students' with strategic process of reading comprehension. Most of them felt helpful in using High Five strategies. A students commented that, "it Could help. Yeah before I got the technique from you I never used technique like that." Other commented that strategies are very important, "Yes absolutely important Miss, so we know the order of the events from the beginning until the end of the story" and "Of course Miss so we can know eee what....intention of the writer." As conclusion, from the findings and data analysis, the researcher may conclude thatthe improvements of the students' reading comprehension of narrative text at XI IPA 2 of SMAN 1 Merangin Jambi were caused and influenced by the students' reading interest and motivation, materials selection, and reading strategies. 


\section{CONCLUSION}

High Five strategies could improve the students' reading comprehension on narrative text. The improvements found in this research were not only the learning result but more precisely the learning process in the classroom. During two cycles in this research, High Five strategies could improve students' comprehension in guessing implied details, identifying paragraph pattern, guessing stated and unstated details, translating vocabulary in context, analyzing generic structure, and writing summary. However, High Five strategies could not improve the students' comprehension in identifying main idea of narratives. In the other hand, it was really effective to improve the students' comprehension in inferring meaning, as Uttl (2002) wrote on his article that its important to estimated verbal intellectual ability in reading.

These improvements were caused students' reading interest and motivation, materials selection, and reading strategies. The use of High Five strategies in reading especially narrative text could cover every step of reading experience with certain strategy. In addition, the selective choice of narrative text titles which suited with the students' background knowledge, and attractive teaching media (powerpoint, video, flashcards, and charts) were really influential in enhancing students' motivation in reading.

There are two suggestions derived from this research: 1) it is suggested to the school to facilitate the teacher who teaches reading in the classroom with appropriate media such as projector and computer, 2) School can have cooperation with the local government to conduct related workshop or seminar in enhancing and training teachers in order to be innovative in using various teaching strategies. 


\section{REFERENCES}

Abu-Rabia, S., \& Siegel, L. S. (2002). Reading, Syntactic, Orthographic, and Working Memory Skills of Bilingual Arabic-English Speaking Canadian Children. Journal of Psycholinguistic Research, 31(6), 661-678. https:/ / doi.org/10.1023/A:1021221206119

Alyousef, H. S. (2006). Teaching Reading Comprehension to ESL/EFL Learners. JLL (Journal of Language Leraning), 5(1), 11.

Atwell, N. (2007). The Reading Zone: How to Help Kids Become Skilled, Passionate, Habitual, Critical Readers. Scholastic.

Drs.), A. S. (Prof. (1998). Pengantar evaluasi pendidikan. PT RajaGrafindo.

Dymock, S., \& Nicholson, T. (2010). “High 5!" Strategies to Enhance Comprehension of Expository Text. The Reading Teacher, 64(3), 166-178.

Faridi, A., \& Bahri, S. (2016). Developing English Islamic Narrative Story Reading Model in Islamic Junior High School (SSRN Scholarly Paper No. ID 2814802). Diambil dari Social Science Research Network website: https:/ / papers.ssrn.com/abstract $=2814802$

Gay, L. R., \& Diehl, P. L. (1992). Research Methods for Business and Management. Macmillan Publishing Company.

Granger, C. A. (2004). Silence in Second Language Learning: A Psychoanalytic Reading. Multilingual Matters.

Guthrie, J. T., Wigfield, A., \& Perencevich, K. C. (2004). Motivating Reading Comprehension: Concept-oriented Reading Instruction. L. Erlbaum Associates.

Hatam, W. R., Sudibyo, D., \& Wibowo, A. (2018). THE EFFECTIVENESS OF STORYTELLING STRATEGY TO IMPROVE STUDENTS' READING COMPREHENSION AT SECOND GRADES OF MTs AL-MA'ARIF 1 KABUPATEN SORONG. Jurnal Interaction, 5(2), 58-67.

Heckelman, R. G. (1969). A Neurological-Impress Method of Remedial-Reading Instruction. Academic Therapy, 4(4), 277-282. https:/ / doi.org/10.1177/105345126900400406

McKernan, J. (1996). Curriculum Action Research: A Handbook of Methods and Resources for the Reflective Practitioner. Psychology Press.

McNamara, D. S. (2007). Reading Comprehension Strategies: Theories, Interventions, and Technologies. Psychology Press.

Mertler, C. A. (2006). Action Research: Teachers as Researchers in the Classroom. SAGE Publications. 
M.Pd, D. R. (2017). Belajar E Pembelajaran: Berorientasi Standar Proses Pendidikan. Prenada Media.

Nelson, N., \& Writing, U. of C., Berkeley Center for the Study of. (1989). Construing constructivism: reading research in the United States. Center for the Study of Writing.

Parks, T. (2014). Where I'm Reading From: The Changing World of Books. Random House.

Pratiwi, W. (2017). THE INFLUENCE OF INDIVIDUAL APPROACH TO TEACH READING VIEWED FROM STUDETS' INTEREST. Pedagogy $\square$ : Journal of English Language Teaching, 5(1), 64-72. https:/ / doi.org/10.32332/ pedagogy.v5i1.768

Smith, F., \& Goodman, K. S. (1971). On the Psycholinguistic Method of Teaching Reading. The Elementary School Journal, 71(4), 177-181. https:/ / doi.org/10.1086/460630

Uttl, B. (2002). North American Adult Reading Test: Age Norms, Reliability, and Validity. Journal of Clinical and Experimental Neuropsychology, 24(8), 1123-1137. https:/ / doi.org/10.1076/jcen.24.8.1123.8375

Wassman, R., \& Rinsky, L. A. (1999). Effective Reading in a Changing World. Prentice Hall. 